\title{
Foreign Prison Experience Resocialization of Prisoners
}

\author{
E.A. Timofeeva ${ }^{1, *}$ \\ *Corresponding author: anna0474@mail.ru \\ ${ }^{1}$ Samara State University of Economics, Samara, Russia and Research Institute of the Federal Penitentiary Service of Russia / \\ Moscow, Russia
}

\begin{abstract}
At the present stage, the analysis of foreign experience in the field of re-socialization of prisoners becomes relevant. One of the main objectives of this article is to consider the problem of the process of re-socialization of prisoners. Among the objectives of this article is to analyze the best foreign experience in this field. The author pays special attention to various types of social, psychological and pedagogical work with prisoners. As a result, the author analyzes modern social and psychological programs for prisoners, contributing to their successful re-socialization. In the process of writing the article used General scientific and private scientific research methods. The leading method of studying this problem is comparative analysis. The result of the analysis was a generalization of the author of the advanced methods of foreign practices in the field of the re-socialization significance of the results is confirmed by isolation of the author of the directions in the process of re-socialization of prisoners, which can be applied as best practices in the activities of the UIS Russia.
\end{abstract}

Keywords: resocialization, foreign experience, social work, prisoner, program, employee.

\section{Introduction}

One of the central problems in the modern Russian penitentiary system is the problem of effective correctional, resocializing influence on convicts and persons released from prison. In this regard, the best foreign experience in the field of re-socialization is being actively studied and analyzed, the principles of work with convicts are changing, the transition from traditional approaches to their correction to the tasks of self-realization and adaptation of their personality in society is being carried out.

Re-socialization of prisoners is the formation in the process of serving criminal sentence personality traits that contribute to the restoration of broken social ties and relationships, as well as the identification of the individual as a subject of their own life. As such qualities are law-abiding and sociality, designed to ensure compliance with human legal norms and its focus on socially useful lifestyle (moral and legal re-socialization).

\section{Problem Statement}

Social work abroad includes a variety of means of re-socialization of prisoners: features of the regime, socially useful work, General and vocational training, educational work. Implement these types and forms of social work with prisoners, as communication with the public through active stewardship Council, the active involvement of religious organizations of various faiths, etc.

\section{Research Questions}

Analysis of the issues of re-socialization abroad shows that modern Western prison paradigms are largely focused on the organization of high-quality social, educational (educational) and psychological work with prisoners. The importance of this will become overcoming various types of deformation, conservation, restoration, the formation of social and personal ties of the prisoner, recovery of its microenvironment, the inclusion of different types of positive activities.

\section{Purpose of the Study}

In this context, the purpose of this article is to consider the problem of re-socialization of prisoners, the possibility of introducing best practices abroad, modern correctional programs, social psychological and educational work. The purpose of the penitentiary social, psychological and educational work is to prevent the deterioration of the situation of a particular prisoner and their groups, to resolve social problems, to update the personal potential to overcome existing and future difficulties or to facilitate (facilitate) the subjective experience of a person, to change attitudes to unresolved situations and problems during the period of imprisonment. Analysis and study of existing foreign experience should 
contribute to the improvement of the penitentiary system of the country, including in the field of optimization of its activities.

\section{Research Methods}

In the process of research General scientific (analysis, synthesis, comparison, generalization), private scientific (historical and legal, etc.) and sociological observations, methods of empirical, social analysis, secondary analysis of sociological data) methods of data collection and processing were used. The leading method of studying this problem is comparative analysis. These methods made it possible to comprehensively study the problem of re-socialization in the penitentiary system, to analyze the best practices of foreign countries, promising for implementation in the domestic penitentiary practice.

\section{Findings}

In the legislation of a number of foreign countries, the main purpose of criminal punishment as a social institution is the re-socialization of the prisoner's personality. The system and process of re-socialization of the prisoner's personality in many countries are connected with the system and process of criminal punishment, have a common structure and differ in specific mechanisms of influence on the person.

The main direction in the work on re-socialization of prisoners abroad is the organization of their training and professional training. To this end, educational, professional and production programs for prisoners have been developed and are being widely implemented in the European Union.

According to Western scientists, about $80 \%$ of prisoners abroad do not have professional and labor skills or have lost them when entering the penitentiary institutions. The factor of education, being accessible to the majority of prisoners, is the most effective in solving the problems of their correction, re-socialization and social adaptation after release.

In Europe, prisoners are offered primary and secondary education. Educational re-socialization of prisoners in Germany is one of the mandatory aspects of social work in prison. In the country's prisons, more than 50 percent of prisoners are involved in training, education, including school programs.

In the Nordic countries, the education of prisoners in prison is seen as a determinant of their subsequent adaptation and re-socialization in an open society. From the first days of serving the sentence, prisoners are provided with systematic information about available courses and educational programs. This makes it possible to create a training program coordinated with the duration of the sentence, and thus to facilitate the rapid adaptation and re-socialization of prisoners.

In Finland, about 10 percent of prisoners improve their education every year. Prisons do not have their own educational institutions, they conclude cooperation agreements with educational institutions. Prisons have the opportunity to provide General education and a wide range of vocational training. Vocational training in Finland is divided into 24 modules, which makes it possible to plan the training process after release. Training is provided in the prison by teachers of vocational education institutions, as well as by prison staff. Prisons that do not have their own educational institutions and teachers organize training in cooperation with external educational institutions. Together with the inspector of education, the social worker decides on the organization of the process of training of prisoners. If the prisoner is in a closed prison, the social worker must agree with the educational institution on the organization of training in specially equipped classes of the prison. After passing the examinations, prisoners can obtain higher education. In some cases, they may attend University without supervision [1].

In Germany, each prisoner has an individual re-socialization programme, which may provide for his or her education, including higher education. Those wishing to obtain higher education enter the closed - type prison Geldern and study in absentia at the University of Hagen.

Thus, the Western penitentiary system is quite clearly focused on the realization of prisoners ' right to education and provides them with the opportunity to learn various educational programs, including higher education [2]. The competent organization of work contributes to the preservation of mental and physical health of prisoners, the creation of collective relations, successful preparation for release and further re-socialization. Production programs are actively involved in the organization of labor.

In Finland, prisoners are given the choice of working hours at the legislative level. It can be work or study. Both activities are paid for by the state. Production activities include Metalworking, carpentry, construction, agriculture, manufacture of fiberglass boats, handicraft production, etc. the working day is 40 hours per week. Weekends are Saturday and Sunday. There are prisons in the country where prisoners are held only at night and work in civilian enterprises.

Turning to the experience of Germany, we can note the successful cooperation of the prison administration with the Federal labor committees and free German trade unions. The prison administration provides vocational education for prisoners. Labor exchanges, together with prison social workers, determine which specialists will be needed in the future for the country's economy. 
One of the most important stages of the process of further re-socialization of prisoners is their participation in professional programs.

In a number of Scandinavian countries, gender-oriented professional programs to prepare women for life at large have been successfully implemented in order to re-socialize women - prisoners. These professional programs of resocialization are very informative in their content. Women prisoners can be trained (Manager, cook, gardener, etc.). In addition, they are taught housekeeping, personal care, useful leisure activities, etc.

In order to implement the professional programs of German prisons, the latest equipment is purchased and supplied to the penitentiary institutions for the purpose of training and work of prisoners in various specialties. The range of professional competencies for them wide enough (an employee of the printing press, welder nuclear reactors, fixer robots on automatic production lines, etc.). In Germany, places of deprivation of liberty are considered a reserve of skilled labor. Social worker agencies monitor and systematize employment information released the prisoner.

Consider a number of examples of the organization of psychological work in this direction. To improve the efficiency of the process of re-socialization, a significant element is the psychological study of the prisoner's personality before the execution of punishment. In Japan, for example, persons admitted to prison are examined in solitary confinement for 15 days. Working with them are experts in different fields with the aim of defining their problems and elaboration of a programme of work with them. For the same purpose, in Germany, all prisoners who have been imprisoned for more than six months are held in the introductory section in solitary confinement. During this period, a survey of the identity of prisoners is carried out, on the basis of which the form of detention, medical supervision, type of work, training, the nature of educational, including religious influence is determined. Similar programs work in 10 States of the USA. The study of personality, based on risk assessment and necessary measures aimed at the resocialization of prisoners, reduces the likelihood of returning prisoners to prison [3].

Special social therapeutic programs (including programs on psychotherapy, group therapy, anger control programs, etc.) are of great importance in the process of re-socialization of prisoners. In the United States, with the direct participation of social workers and psychologists, the implementation of a number of the above programs is quite successful. For example, programs designed to overcome drug addiction are widespread: 1) alcoholics anonymous; 2) on the destruction of drug dependence for prisoners on probation (designed for prisoners who have achieved conditional release, but violated its conditions due to drug use or related behavioral problems); 3) for criminals with short prison terms-the program is designed for prisoners whose sentence does not exceed 58 months, and all offenders of conditional release. (prisoners whose crime was connected with drug or alcohol consumption are involved); 4) long-term intensive overcoming of drug dependence. In Germany, through specialized therapeutic measures aimed at providing social assistance and benefits to prisoners, they are successfully re-socialized and prepared for release [4].

One of the main approaches to work with prisoners is the programme-specific approach, expressed in the programme of behavioral modification and technologies, which have been put into practice in the country's social and therapeutic institutions, as well as in the Netherlands and Denmark. Prisoners with a deformed personality, sex offenders, persons found to be of limited responsibility, as well as young offenders who have already been sentenced to imprisonment twice, are sent to social and therapeutic institutions in Germany. The purpose of detention in social and therapeutic institutions is to develop the ability of the persons there to lead a responsible life in the future and not to commit criminal acts by means of special therapeutic means and social assistance. Measures of direct coercion are not applied to a person placed in a social and therapeutic institution on a voluntary basis. The above-mentioned persons may be released from social and therapeutic institutions upon their request.

In many countries, the re-socialization of HIV-infected prisoners and the prevention of AIDS in prisons are problematic. Medical and social workers abroad regularly carry out the necessary awareness-raising activities among prisoners about their social guarantees. There is a ban on free blood tests for all prisoners, especially at risk. Despite the principle participation of HIV-infected prisoners in all activities of the institution, there are restrictions for this category of prisoners in the form of their increased isolation at night and in the workplace.

Due to the increase in the number of prisoners suffering from mental disorders, medical rehabilitation and correction programs are extremely popular and relevant. For example, in the United States, Canada, Australia widely used rehabilitation Program-model Risk-Need-Responsivity, designed specifically for the treatment and rehabilitation of prisoners with mental disorders. The program is aimed at reducing the recurrence of crime, and to obtain clinical, social and psychological effects. The purpose of the model program is to influence the criminogenic needs of prisoners (needs to commit crimes). In the implementation of the program, the model takes into account the individual characteristics of the individual in order to understand the possibility of the variability of criminal behavior and its recurrence. Formed a special modification of the work plan concluded with a consideration of the needs, risks, General and specific sensitivity.

The period of preparation of a prisoner for release and the post-penitentiary period of re-socialization are recognized as an equally important element of penal policy worldwide. In the United States, prisoners, including the disabled and the elderly, are placed in a specialized institution one year before release to adapt to their return to society. In such institutions, they receive vocational training for work, family psychology courses, etc. Prisoners are provided with all assistance in the local employment service, as well as the necessary medical care.

The experience of Great Britain, England, Germany, the USA, Finland, France, and other countries shows that the additional financial costs associated with the implementation of post-penitentiary programs are subsequently repeatedly compensated by the reduction of budget expenditures for serving new prison terms [3]. 
As an example of effective integration of foreign experience in the field of re-socialization, we can cite the implementation over the past 7 years of the Russian-Swiss project dedicated to the training and retraining of specialists in social work dealing with the problems of re-socialization of convicts in the Russian penal system. Within the framework of this project, the Swiss side provided material and methodological assistance in training specialists in social work for Russian penitentiary institutions.

\section{Conclusion}

The analysis and generalization of the foreign practice of the Institute of re-socialization allow us to distinguish the following conclusions. Among the important areas of the process of re-socialization of convicts, which can be applied in the activities at the present stage of reform of the penal system in Russia:

- monitoring the effectiveness of social, psychological and pedagogical work in prisons;

- ensuring the social and economic basis for the work of the re-socialization system, including the attraction of additional sources of funding in addition to the Federal budget (public, non-profit organizations, etc.);

- creation of new programs of correction of social and psychological behavior of the convicted person, paying special attention to the period before the execution of punishment and preparation for release in order to improve the social efficiency of the process of re-socialization;

- the development of mechanisms for cooperation with commercial enterprises in the use of convict labor, for example, by providing tax benefits, placing state orders;

- determination of the most and least effective working divisions (employees), identification of the reasons of the inefficiency of activity of employees, divisions, and preparation of the corresponding recommendations by chiefs of divisions;

- the creation of an automated information Bank of the results of the activities of social and psychologicalpedagogical work units;

- development of mentoring during release (policeman, relative, social worker);

- development at the state level of the program of re-socialization with the mechanism of financial stimulation of convicts for participation in rehabilitation programs.

As a conclusion, it should be noted that the research, summarizing the foreign experience in the field of resocialization of prisoners, allows allocating funds and methods that can be successfully applied in the activities at the present stage of reform of the penal system in Russia.

\section{References}

1. E.A. Timofeeva, S.S. Piyukova, O.V. Oschepkova, The organization of process of training of the convicts in Higher educational institutions in conditions of serving of imprisonment: methodical recommendations. Samara: Samara law Institute of the FSIN of Russia (2017). [in Rus.].

2. E.Y. Leonova, L.L. Mehrishvili, An experimental model of educational re-socialization of convicts: The adaptation of Russian and foreign experience. Bulletin of the Chelyabinsk State University, 24(353), 107-110 (2014). [in Rus].

3. V.V. Zagarskikh, Financial practice of re-socialization of convicts taking into account foreign experience. In A.S. Yakimov, A.I. Abaturov, I.A. Ivankov, V.V. Zagarskikh, L.V. Rudakov, O.G. Arslanova, A.I. Mukhailov (Eds.), Institute of resocialization of convicts: State, problems and prospects of development": collection of materials of the all-Russian scientific and practical conference 2017 (pp.98-101). Kirov: PKU DPO IPCR the Kirov Federal penitentiary service of Russia (2017). [in Rus.].

4. E.A. Timofeeva, On the possibility of integration of foreign experience in the activities of the Russian penal system at the present stage. II international prison Forum "Crime, punishment, correction": Collection of abstracts and reports of the participants. Vol. 1: Proceedings of the plenary (pp. 346-354). Ryazan: Academy of the Federal penitentiary service of Russia (2015). [in Rus.]. 